\title{
WebGIS and Geospatial Technologies for Landscape Education on Personalized Learning Contexts
}

\author{
María Luisa de Lázaro Torres ${ }^{1}$ [D, , Rafael De Miguel González ${ }^{2, *}$ and Francisco José Morales Yago ${ }^{1}$ \\ 1 Geography Department, Universidad Nacional de Educación a Distancia (UNED), Madrid 28040, Spain; \\ mllazaro@geo.uned.es (M.L.d.L.T.); fjmorales@geo.uned.es (F.J.M.Y.) \\ 2 GEOT-IUCA Research Group, Universidad de Zaragoza (UNIZAR), Zaragoza 50009, Spain \\ * Correspondence: rafaelmg@unizar.es; Tel.: +34-876-554-845
}

Received: 24 August 2017; Accepted: 3 November 2017; Published: 8 November 2017

\begin{abstract}
The value of landscape, as part of collective heritage, can be acquired by geographic information systems (GIS) due to the multilayer approach of the spatial configuration. Proficiency in geospatial technologies to collect, process, analyze, interpret, visualize, and communicate geographic information is being increased by undergraduate and graduate students but, in particular, by those who are training to become geography teachers at the secondary education level. Some teaching experiences, using personalized learning, distance learning methodology, and GIS, focused on education aims to integrate students and enhance their understanding of the landscape are shown. Opportunities offered by WebGIS will be described, through quantitative tools and techniques that will allow this modality of learning and improve its effectiveness. Results of this research show that students, through geospatial technologies, learn the landscape as a diversity of elements, but also the complexity of physical and human factors involved. Several conclusions will be highlighted: (i) the contribution of geospatial training to education on the landscape and for sustainable development; (ii) spatial analysis as a means of skills acquisition regarding measures for landscape conservation; and (iii) expanding and applying acquired knowledge to other geographic spaces.
\end{abstract}

Keywords: WebGIS; landscape; heritage; personalized learning; the cloud; distance learning

\section{Introduction}

The increased use of the Internet has made the use of online interactive digital maps based on open data possible instead of conventional cartography on paper. In the late 1990s, "GIS [was] traditionally seen as an enabling technology for improving the understanding of spatial problems by means of engaging students in empirical analysis" [1]. After twenty years, learning about the urban world with spatial data visualizing shapes and making metrics online allow Lynch's concepts to be transposed [2] to digital format.

All of these challenges have to be faced [3]: (i) innovative curriculum: content, cognitive processes, assessment, outcomes, competencies, etc., versus encyclopedic geography; (ii) updated topics: geography for life and spatial challenges in the 21st century: environment, sustainability, climate change, population pressure and migration, food and water supplies, transportation, city growth and housing in urban and metropolitan areas, and energy supplies; and (iii) pedagogies: textbooks versus inquiry-based learning (IBL), problems-based learning (PBL), students simulating scientific tasks of geographers, and learning by doing geography.

All of these aims make geospatial technologies helpful, as they allow obtaining, processing, and presenting geographic information. It has been demonstrated that geospatial technologies using geoinformation and WebGIS [4,5], Augmented reality [6], or 3D [7] contribute significantly to the development of students' geospatial thinking 


\section{The Educational Context}

The educational context should reflect and respond to three main questions, what to learn, how to learn, and who will learn, to carry out the construction of a training strategy that integrates the most appropriate resources and tools for each student according to their own background. This approach to personalized learning or personalized education is a pedagogical concept that tries to achieve the best possible integral human development for every student. Thus, efficiency and effectiveness are important elements as learning objectives in order to improve learning outcomes and to reduce university attrition and school leavers. Its application is a challenge, especially in distance learning. Active methodologies, and personal and cooperative work [8] are essential to this methodological renewal.

\subsection{What to Learn}

Landscape, as an expression of the territory, is the main object of study in geography. The landscape is the result of the interrelation of physical and human elements. The European Landscape Convention (2000) [9] reflects how important this is.

The visualization of landscape, through digital images, allows observing the most characteristic elements and can help to establish homogeneous units according to them: the physical environment (relief, vegetation, presence of water or climate), but also anthropic action (population, economic activities, and infrastructures). Images of previous times show elements of natural and cultural heritage that still survive or have been lost. Therefore, it is possible to understand the future of the landscapes represented, their quality, and the conservation measures needed. Of course, fieldwork is very important to complete landscape monitoring and environmental assessment [10], but this is not always possible. Thus, geospatial technologies arise as an important tool for a landscape approach in learning.

The importance of the existing landscape with respect to the heritage of Spain, and also around the world, is a unanimous fact not only based on the protected natural areas which comprise more than $20 \%$ of the Spanish territory, but also the declared world heritage by UNESCO, with 47 sites declared: "Spain has a preferential situation in terms of assets declared world heritage, specifically the third world power behind Italy and China. This privileged position is a clear indicator of the need to manage this wealth in an educational way. The greatest interest lies in the safeguarding of the heritage, its approach to the population, its care, transmission, dissemination and enjoyment" [11]. These previous reasons encourage the promotion of heritage education and landscape education in a holistic approach to citizenship education. There are two Spanish documents to define these aims, the National Education and Heritage Plan (2013), and the Heritage Education Observatory in Spain [12] coordinated by the State and the Autonomous Communities. Heritage education is understood as an essential discipline to connect natural and cultural heritage with the acquisition of social and civic key competencies and powerful knowledge in geography, history, biology, environment, etc., and, of course, landscape heritage. The school education system reflects this concern in the national curriculum, forcing universities to prepare future teachers and citizens with a basic kit of tools for landscape and environmental assessment.

\subsection{How to Learn}

The pedagogical model created by Pierre Faure for personalized education [13] is widely used and was based on two pillars: one is the integral vision of the human being, and the other is the constructivist method. The latter encourages the personal work of the student in a guided way, and a subsequent grouping or group interaction based on previous knowledge obtained through personal work. The constructivist method proposes the integral development of the person by forming responsible citizens, from their own work at school. Students discover their learning challenges; they engage in learning and in researching; and they increase their competencies in learning to learn. This enhances a responsible citizenship, acting with knowledge and integrating life-long learning in 
a natural way. The essence of personalized learning makes the student take the initiative of their own work: establishing their own learning objectives, managing the content to learn according to their own background and interests. The possibility of communicating with others is also a relevant question, putting into practice their social skills supporting life-long learning. Thus, the student-centered learning is "pushed" not only by the teacher's orientation but also by the community and network.

Some specific teaching and learning strategies, such as the inquiry method [14-16], the flipped classroom or flipped teaching [17,18], self-organized learning (the Self-Organized Learning Environment, SOLE project [19]), self-learning and life-long learning [20] are examples of student-centered learning guided by teachers using personalized learning. In all cases, key questions of the subject to be studied or researched are very important in order to achieve learning objectives using a varied range of materials. The student should choose within useful resources for the subject. There is a great flexibility in personal work: without distances, without schedules, using group and teacher interaction.

The sequence of learning entails the continuous and creative intervention of the teacher by encouraging and guiding the use of different didactic strategies and resources. The demand for a methodological renewal is only possible with initial and in-service teacher training. "There is a growing emphasis in higher education on deeper learning approaches, defined by the William and Flora Hewlett Foundation as the mastery of content that engages students in critical thinking, problem-solving, collaboration, and self-directed learning" [21] (p. 12).

The pedagogical model should help to learn landscape content using ICT (Information and Communication Technologies). Mishra and Koehler [22] introduced the Technological Pedagogical and Content Knowledge (TPACK) model as a useful frame for describing and understanding the goals for technology use, not only in geography teacher education [23], but also on primary, secondary, and tertiary education [24,25]. The model is not specifically aware of personalized learning as a PLE (personalized learning system), but it has a very useful reflection on how to connect content, technology, and pedagogy. It would be very interesting to combine both approaches, in the future, and stress personalized learning in order to teach students how to think and discover new ways for personal development.

\subsection{Who Will Learn}

The increased number of students in the classrooms at all educational levels, after the economic crisis generated on 2007, with great cuts in education in the national budget, undoubtedly makes the application of personalized learning methods difficult because a small number of students seems more suitable. Technologies and geotechnologies (GeoICT) make it possible to introduce custom processes without undue stress. In fact, after a review of the literature related to the personalized learning environments (PLE), it concludes that it is imperative to improve the quality and quantity of technology used to aid the learning process [26]. The TPACK model attempts to solve this problem [27]. The personalization of learning, nowadays, has an increasing weight in society. Using ICT, however, does not guarantee integral human development for every student, in its broadest sense, with respect to higher-education students, future teachers, and students of primary and secondary level education. On the other hand, there are still complex problems to solve, such as managing knowledge obsolescence and rethinking the roles of educators [21] (pp. 32-35).

\section{Objectives and Methodology}

The present paper shows some learning examples of the usefulness of geospatial technologies and ICT for landscape education underlining the importance of pedagogical methods to achieve personalized learning, particularly focused on distance learning.

The main objectives of the learning experiences are:

- To obtain a better understanding of the landscapes using different tools for spatial analysis. 
- To increase digital and geospatial competencies to apply acquired knowledge to other geographic spaces and different landscapes.

- To encourage active student constructivist learning, building up their own knowledge.

- To apply territorial knowledge in daily life by acting wisely with responsibility for sustainable development.

Learning and understanding about the landscape is not a new aim, as four different and clear actions [28] could be considered as being close to the adapted Bloom taxonomy [29]:

1. Perceiving and observing (territory), some key questions help these tasks.

2. Using: Acquiring, exploring, organizing, analyzing, and interpreting outdoor and other geospatial technologies used.

3. Analyzing layered map data to understand the complexity of the elements involved in the organization of territory (physical, social, economic, political, and cultural) resulting from their interaction.

4. Structuring: Making sense of collected geographical information (geoinformation). Structuring spatial relations, such as identification, comparison, measurement, connections, directions, or hierarchy, among others.

5. Applying: Acting on the correct and wise use of geographical knowledge (e.g., building new interactive maps with student's own data and obtaining new research conclusions).

The inquiry method is widely applied to spatial analysis to achieve landscape monitoring and environmental assessment.

These steps, focused on learning about the landscape, will be discussed throughout this paper using geoinformation and different tools based on geotechnologies and ICT: (i) WebGIS, defined as a geographic information system on the cloud; (ii) a peer review tool, Aropä, a learning environment which allows the organization of the correction of dissertations, essays, or other works, by double-blind peers, using evaluation rubrics [30]; and (iii) electronic portfolios, which are significant elements for personalized learning objectives.

In order to achieve these objectives the learning examples that enhance personalized learning based on geotechnology and ICT to learn about the landscape will be explained in Section 4, followed by conclusions and results.

\section{Learning Examples Based on Geotechnology, ICT, and Personalized Learning}

Technology allows students to access a wider variety and quantity of instructional resources and each student can choose which material or resources to use for a better learning. Different methods and different speeds of learning can be faced by ICT according to the students' interests and experience. The very large amount of information available on the Web makes it necessary to assess the quality of the online material and this is also applicable to the wide variety of Internet tools, in order to select the most appropriate. Different supports (video, text, graph, and maps, among others) have the same content to be used and they can host tasks, correct them, and analyze and monitor the entire learning process using learning platforms. Technology makes the objective of promoting personalized learning possible with the teachers' orientation, which must be adapted to each student. Some authors call it adaptive learning [31,32]: the adaptability in the process, the training plan, and in self-learning to respond to the needs of students. In this method of learning-very useful for distance learning - the medium is adapted using tools, such as video, related to flipped teaching to favor this type of "à la carte" teaching method, and also virtual learning environments, such as the Moodle platform, so that th student can learn. These platforms allow the teacher to add and delete content according to the needs of the students, selecting the materials needed for each group of students, proposing key questions to promote learning, dividing students into interest groups for participation in forums and inviting students to create their own blog. They are an essential element of asynchronous interaction and personalized feedback, for example, through the same forums and 
messages of support. Educational Adaptive Hypermedia Systems (EAHS) make the adaptation to students possible. Some distance universities, such as the Spanish Universidad Nacional de Educación a Distancia (UNED), use many different channels to promote adaptive systems.

The growth of open learning environments, such as the Massive Open Online Courses (MOOC), allows creating one's own itinerary of learning between the variety of resources that these courses present, adding opportunities for personalized and collaborative learning.

Personal learning environments are classified as follows (Figure 1) [33]: courses, such as the above-mentioned open MOOC, conferences, scientific working groups, online symposia, podcasts and media casts, among many others. Adaptive teaching uses personalized learning.

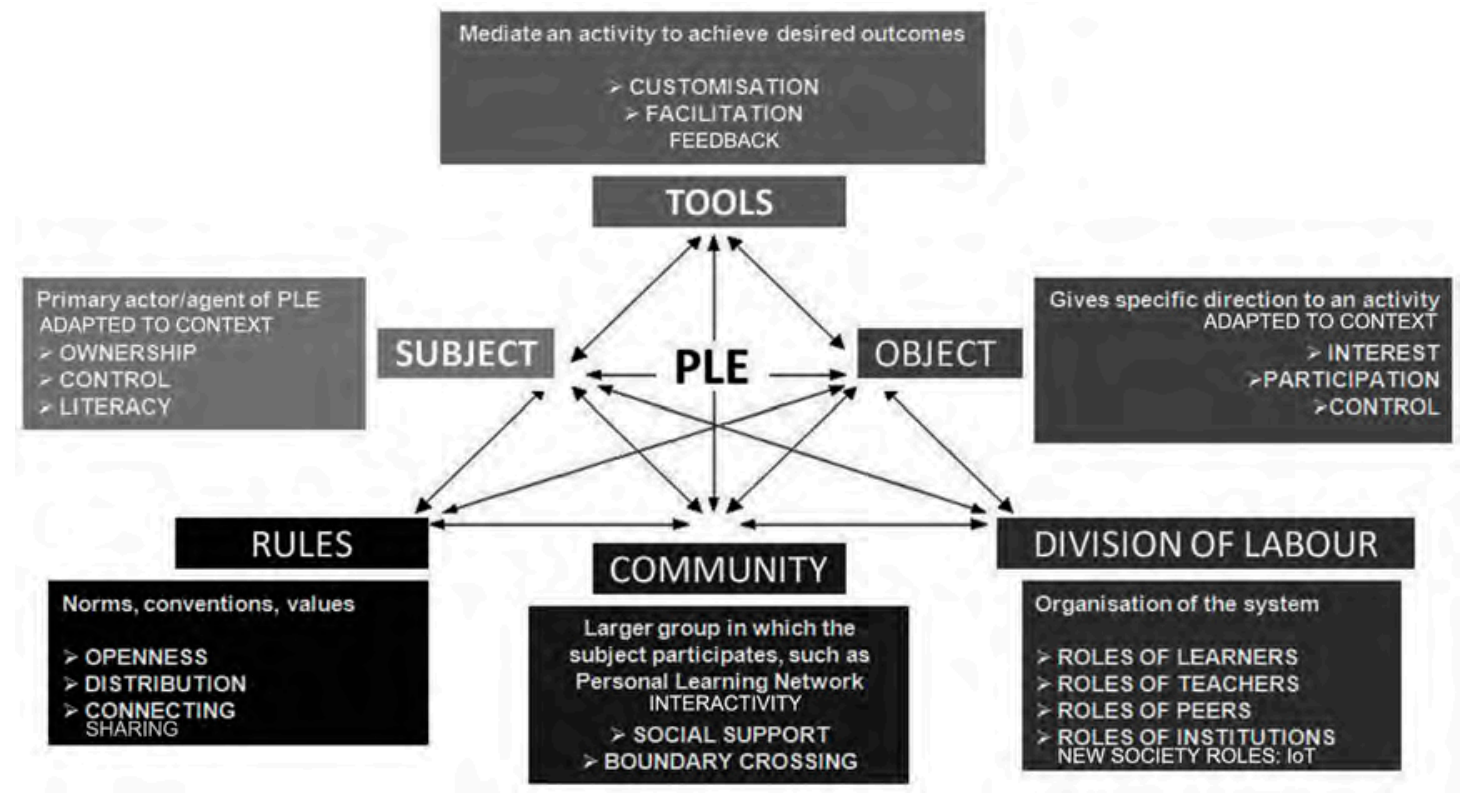

Figure 1. Elements of a personalized learning system (PLE), adapted from [33] (p. 30).

The system needs to be adapted to the educational context, with all the elements listed so far. Methods and technology as a means of applying personalized learning are emphasized by many European projects, such as the School on the Cloud project. Partners gathered experiences to be analyzed from the point of view of personalized learning, using a series of indicators [34] (p. 15), and showing how difficult it is to achieve personalized learning with the results of this analysis. Most of the experiences do not meet the objectives or the methodology of personalized learning.

Martínez [35] concludes that researchers are making rapid progress by realizing the dream of personalized learning with object architecture and adaptive learning technology. However, an understanding of the whole person, of how people want or intend to learn, rather than simply building, processing and storing knowledge is still missing from most online solutions.

\subsection{Learning Landscape Using WebGIS}

WebGIS is a geospatial technology using geoinformation on a geographic information system online, which allows the collection, processing, analysis interpretation, visualization, and communication of data, adding and removing layers, and client-server interaction. The existence of WebGIS comes from three recent developments under the geospatial technologies revolution [36]: (i) the widespread use of GPS (Global Positioning System); (ii) access to open data (geodata) and quality images; and (iii) the proliferation of cloud applications and WebGIS platforms, such as ArcGIS Online (AGOL), Boundless, Carto, GeoNode, Mango, or Mapbox.

Therefore, to integrate geodata, images in different layers, gather a data collection on a map for a further analysis [37] on a Web map on platforms hosting GIS on the cloud, and integrate 
other data from participatory methods using a computer or a device (e.g., ESRI Survey123) are easy tasks. The WebGIS platforms offer a great amount of free geodata in layers on which it is possible to add your own geodata. Thus, geodata can be added more easily than some years ago to create interactive maps on the cloud. Geodata can be displayed on different devices for visualization, measurement, and analysis of features of the Earth. This opens new possibilities for teaching and learning geography, for spatial analysis of the information contained in a WebGIS [38], for spatial case studies in a particular area.

These geospatial technologies using geoinformation make it possible to understand landscape transformations and, thus, environmental monitoring and assessment. This geospatial approach has been previously used in GIS training by several European projects, such as GeoSkills [39], digital-earth.eu, or even by the European Environment Agency initiative called Eye On Earth.

By using WebGIS, students can visualize geographical content on a spatial basis, interacting with other users and contributing to add new content. GIS in the Cloud (WebGIS) makes possible a new approach in geography and landscapes education.

\subsubsection{WebGIS on University Projects}

Innovative teaching projects at the Complutense University (PIMCD) [40-42] allowed the GEODIDAC research group to work on landscape education (a selection of them are in Table 1), combining flipped teaching, collaborative methods, and cloud-based GIScience learning [17].

Table 1. Innovative teaching projects (PIMCD) (see also Appendix A).

\begin{tabular}{|c|c|c|c|}
\hline Title (No/Year) No Downloads & Main Topic & Approach to Spanish Landscape & Tools \\
\hline $\begin{array}{l}\text { Teaching Geography, image } \\
\text { analysis, Virtual Campus and } \\
\text { the Interactive Whiteboard (IWB) } \\
(6 / 2010) 2816\end{array}$ & $\begin{array}{l}\text { Analysis of } \\
66 \text { landscape images }\end{array}$ & $\begin{array}{l}\text { Observation, analysis and commentary of } \\
\text { landscape elements and units; relationship } \\
\text { with the sustainable economy and with } \\
\text { society (equilibrium or imbalance of that } \\
\text { landscape with its environment and with } \\
\text { economic development). }\end{array}$ & $\begin{array}{l}\text { AGOL WebGIS, Google } \\
\text { Earth, Picasa, Moodle } \\
\text { virtual campus, IWB }\end{array}$ \\
\hline $\begin{array}{l}\text { Learning Spanish geography on } \\
\text { the Web } 2.0(165 / 2013) 218\end{array}$ & $\begin{array}{l}\text { Itineraries on } \\
\text { patrimonial and natural } \\
\text { landscapes }\end{array}$ & $\begin{array}{l}\text { Observation, analysis, comment and } \\
\text { assessment of landscapes creating itineraries } \\
\text { to be carried out on foot with a maximum } \\
\text { duration of } 4-6 \mathrm{~h} \text {. Images representative of } \\
\text { georeferenced points of interest. }\end{array}$ & $\begin{array}{l}\text { AGOL WebGIS, Iberpix, } \\
\text { Moodle virtual campus }\end{array}$ \\
\hline $\begin{array}{l}\text { The challenge of the Cloud for } \\
\text { fieldwork: the Sierra de } \\
\text { Guadarrama N.P.1 (224/2015) } 53\end{array}$ & $\begin{array}{l}4 \text { Itineraries around this } \\
\text { National Park }\end{array}$ & $\begin{array}{l}\text { Itinerary description; accessibility; } \\
\text { topographic profile; panoramic image; } \\
\text { objectives and competencies of each } \\
\text { itinerary; points of interest: geolocated } \\
\text { image, explanation and activities; references. }\end{array}$ & $\begin{array}{l}\text { AGOL WebGIS, Moodle } \\
\text { virtual campus }\end{array}$ \\
\hline $\begin{array}{l}\text { Application of GeoICT in } \\
\text { the design of itineraries for } \\
\text { landscape education in the field of } \\
\text { Spanish National Parks } \\
(52 / 2016) \text { n.d. }\end{array}$ & $\begin{array}{l}\text { Itineraries inside each } \\
\text { of the } 15 \text { Spanish } \\
\text { National Parks }\end{array}$ & $\begin{array}{l}\text { General description of each park, problems; } \\
\text { itinerary, accessibility, topographic profile, } \\
\text { panoramic image, points of geographic } \\
\text { didactic interest, geolocated image of each of } \\
\text { them including general explanation, } \\
\text { objectives, activities and other aspects; } \\
\text { bibliographic references and web pages. }\end{array}$ & $\begin{array}{l}\text { AGOL WebGIS, Moodle } \\
\text { virtual campus }\end{array}$ \\
\hline
\end{tabular}

The technical advantages of web mapping created from images of agricultural landscapes and geographical itineraries [43], among many others, became evident when these georeferenced images-including comments and metadata-were turned into a conventional web page very easily 
and quickly. This is just the opposite to the previous system: creation of web maps using html, which meant a great investment of time, a location that was not always precise, the inability to integrate other layers of information that enriched the context of the images, and a lack of collaborative work in real-time.

About ten complex mapping projects have created new WebGIS materials for the Master's teachers classroom since 2012 and around five hundred students have benefited from this way of teaching and learning. The published projects on e-prints of the Complutense University of Madrid have more than 5000 downloads of the publications in the new system of downloads (17 May 2017), which evidences the acceptance of this way of teaching and learning.

These projects have been key to shifting teaching methodologies of many of the teachers participating in them. The flipped teaching method has been a great help in the creation of web maps, following these main steps: students gather data and materials autonomously (for example, an image of an agricultural landscape), then they interpret it with the help of the teacher. Later, they create their map with the geoinformation previously gathered. The teacher mentor overviews and helps students with the technical difficulties. The last step is to create a collaborative web map with the contents and geodata gathered jointly with the content of the WebGIS, which already covers the subject of study; for example, the vineyard landscapes of Spain. The multi-causality approach to the landscape, from the gathered information, makes students think about it and become aware of sustainable development. This method of working the Spanish landscape can be exported to other places in the world.

The user creates different collaborative web maps by themes that show different landscapes [44] or itineraries in zones of heritage or landscape interest, for example, Spanish national parks [45] or Madrid old Walls (Figure 2), enabling questions and possible teaching activities.

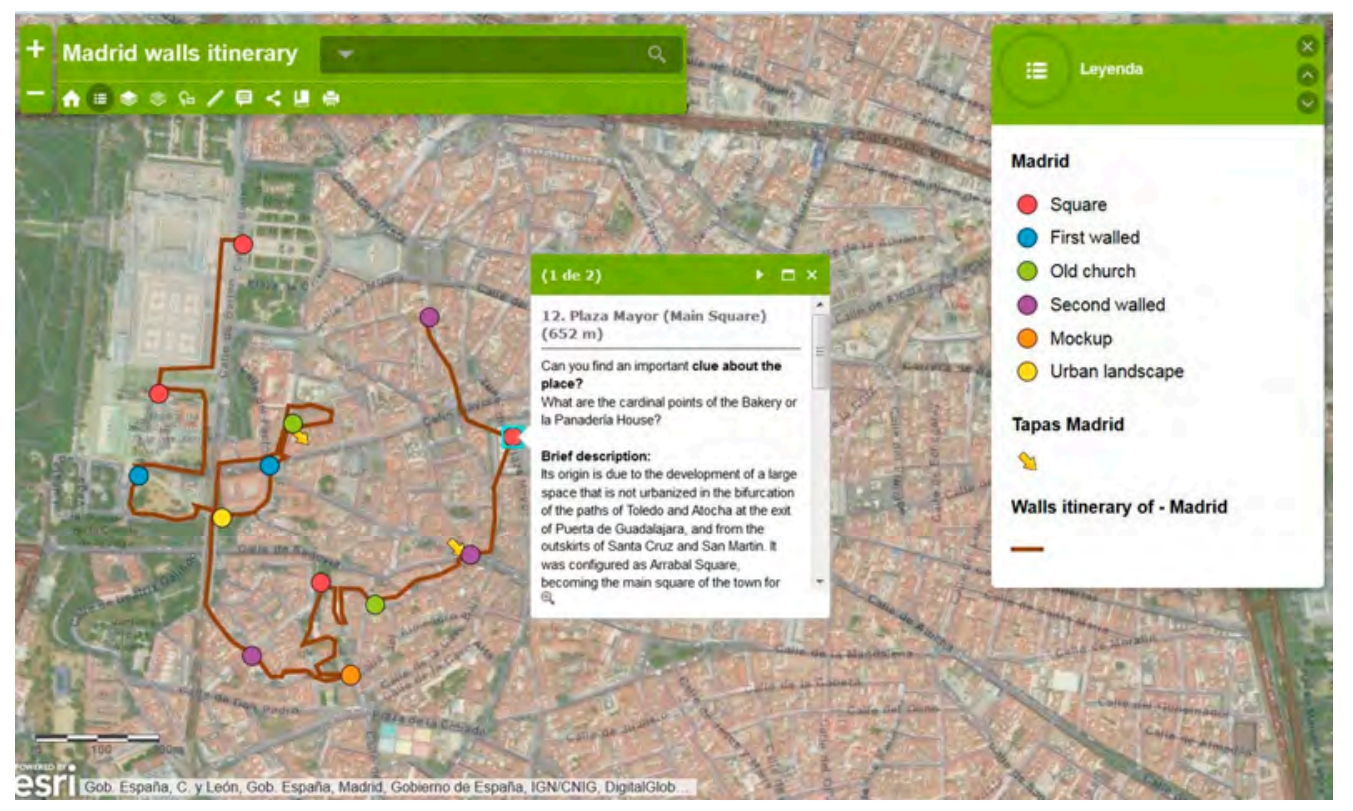

Figure 2. WebGIS about Madrid origin, historical center and heritage using an itinerary around the old walls (Madrid, Spain).

The student teacher's work, future teachers of geography for secondary education at several Spanish universities, showed their satisfaction by constructing their own cartography and applying them to their own classrooms during their traineeship period. Some of those questioned agreed that "it is important to learn how to handle students in a different way than traditional paper as WebGIS are much more visual and it is easier and more comfortable to work with the interactive online maps. It is a more dynamic and close to the student for the applied study of different questions of geography". 
It can be concluded that this method using WebGIS reinforces learning that satisfies students, and even in-service geography teachers, who have collaborated asynchronously from different places. These same teaching strategies have been used in topics that are easily outdated on geography school textbooks, such as geopolitics, population, economy geodata, etc.

\subsubsection{Digital Atlas for Schools}

The Digital Atlas for Schools (in Spanish, Atlas Digital Escolar, ADE) (accessible at atlasdigitalescolar.es) (Figure 3) is a set of maps drawn from the previous WebGIS experiences of the mixed team, composed by geography educators at colleges and teachers of geography at K-12 levels.

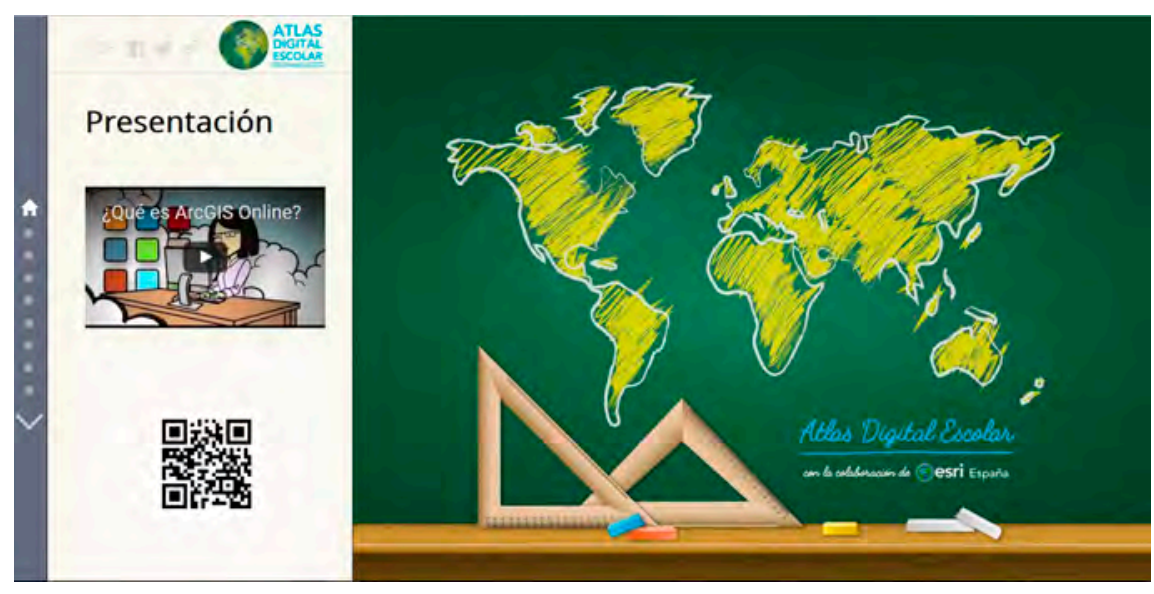

Figure 3. Digital Atlas for Schools front page.

This geospatial tool has clear pedagogical advantages in learning methods [46]: increased motivation, improved perception and better spatial thinking, collaborative work, meaningful learning by doing, spatial analysis, project-based learning, geospatial accuracy, etc., at all educational levels, but mainly at secondary schools. The Atlas is the result of a contract between the University of Zaragoza and ESRI Spain. Thanks to the dissemination and the recognition of several institutions (Spanish Royal Geographic Society, EUROGEO, IGU Commission of Geographical Education) it has reached about 60,000 users in two years since it was launched, according the data provided by Esri Gallery. Most Spanish—and even some Latin American—universities use Digital Atlas for Schools as the main tool for geography teacher training programs.

The Digital Atlas for Schools uses ESRI technology and it is visualized through ArcGIS Online, in a storytelling format. "ArcGIS Online is an online, collaborative web GIS that allows you to use, create, and share maps, scenes, apps, layers, analytics, and data" [47] and also to create working groups. The version for organizations is free for education in the USA and has as a specific project now extended to some European countries: the interaction with ArcGIS Desktop, and the facilities given to the ADE project for using ArcGIS Online (AGOL) ${ }^{\mathrm{TM}}$, the ESRI ${ }^{\circledR}$ WebGIS platform lead to the birth of the "Atlas Digital Escolar". The platform allows creating customized maps that reflect the results of an investigation and adapt them to the educational needs. It is also organized in the form of a Web mapping, making the integration with all the geoinformation resources possible: map notes, WMS or WMTS layers (raster), tracks on gpx, csv databases, shp files for vectorial mapping, etc.

Information obtained from statistical or cartographic open sources, such as EUROSTAT, International Monetary Fund (IMF), or World Bank (WB) Excel tables and Spatial Data Infrastructures (SDI) services, among others, can be easily integrated into a web map on AGOL. The WebGIS platform allows addressing the geospatial challenges and problems of Europe and the world. Thus, for the preparation of the Atlas, open data are used, previously published by the statistical institutions responsible for every data source, which guarantees its quality. For example, a better knowledge 
of Spain comes from the open data of the Spatial Data Infrastructures of Spain (IDEE) maintained by the National Geographic Institute (IGN) and the Spanish Statistic Institute (INE). Possibilities for creating and updating the created maps would be increased from a combined use of ArcGIS Online and ArcGIS Desktop.

The Atlas is structured in seven sections (more than one hundred maps and almost four hundred geoinformation layers): (1) How it works; (2) Cartographic tools; (3) Physical geography and environment (landscapes); (4) Population and urban geography; (5) Economic geography and globalization; (6) Spatial imbalances and regional planning; and (7) School projects with AGOL.

A web mapping application with text, videos, maps, and class resources are essential components of the Atlas. The toolbar includes zoom, legend, information about the layers, the option of changing the base map, making measurements, and sharing and printing. There is a popup window which shows map details and gives further information about the map [48]: targeted students, on topics covered, enumerated layers and information presented on the map web. There are two available links: the first one leads to what has been described as an ArcLesson. It has examples of questions that can be directed at students to deepen their knowledge of the issues presented, a very useful instructional resource which can be downloaded; and a second link to the web map contains the built-in application for teachers or students registered to access the map information, activate the layer, or modify or create a new map from this ADE map, which is only possible by logging in to one's own AGOL account.

The main objectives to be achieved with the Digital School Atlas are:

- Facilitating the acquisition of knowledge based on the geography curriculum.

- Encouraging critical geospatial thinking [49], providing a tool for spatial analysis.

- Understanding the concepts and reflected contents on any map, rather than memorizing it. This invites browsing to reach the same learning outcomes proposed by the current curriculum.

- Leveraging open and quality geodata available on the portals maintained by the official bodies responsible for the same data.

- Promoting learning standards and evaluation criteria that are useful for learning throughout life-centered and spatial reasoning, and acquiring digital skills.

- Learning how to properly integrate geolocation tools in pictures, maps, and other geo-data to help gain a better understanding of the Earth, through its analysis and by drawing the right conclusions for actions to be taken.

- Forming a citizenship whose responsibility is to apply acquired knowledge. Study cases and school experiences will be proposed with this aim in mind.

- Serving as a laboratory instrument for geography education research in at least two ways: geospatial thinking and GeoProgressions [50].

Every teacher or student (future teacher) using ADE expressed the learning potential of the tool on a survey at the end of ADE activities in geography lectures and lessons. Few problems have been encountered by the Master Teachers students focused on the Wi-Fi, the resources of the class, age of the students, their background, and the theme of the lessons. The tool fits with personalized learning as it allows working different topics at different depths. The ADE has been used with Complutense and Zaragoza Masters' Teacher since 2015 using IBL and PBL methods.

\subsection{The Aropä Learning Environment and a Landscape Approach}

The Aropä learning environment helps to establish evaluation rubrics that respond to learning objectives and content, allowing teachers to organize double-blind double-corrections online and offer the accurate results of them, permitting personalized learning using a distance methodology.

To assess the natural heritage impact is not an easy task for students. The efficiency of land management is possible by consulting and studying the current legislation related to the uses of land in natural spaces. In this context and, as a complementary means of learning, students from the Environmental Sciences degree at UNED: Planning of the Territory II (2016-2017 academic year), 
must carry out an assessment of one of the National Parks of Spain (Figure 4). An essay or dissertation is planned consulting current legislation, researching the main problems, and correcting two other student's dissertations or essays as blind peers. It is not a compulsory activity for them, but those who participated in it enjoyed this new way of shared learning.

The statement of instruction proposed to the students was: Write an essay on the topic "Difficulties and problems of the land use management of a National Park", which will be corrected by two of your colleagues (blind peers). Some guidelines were given [51] on the format, the structure of the document to be elaborated, and the content, such as a personalized title. A synthesis of the analysis of the documentation related to the park, from geospatial products, the enumeration of the physical elements, and indicators of the most relevant physical environment and problems of management of the park were also provided. An argument of whether the planning proposals in the park needs to be implemented or not was included, and how to develop a sustainable spatial strategy for the area was asked. After the date of delivery of the work, the system assigns two essays about different parks to be corrected by the student. The keywords established by the teacher, which were the names of the parks, labeled the essays, allowing the system to award two parks different from the one already studied, and uploaded them the Aropä platform.

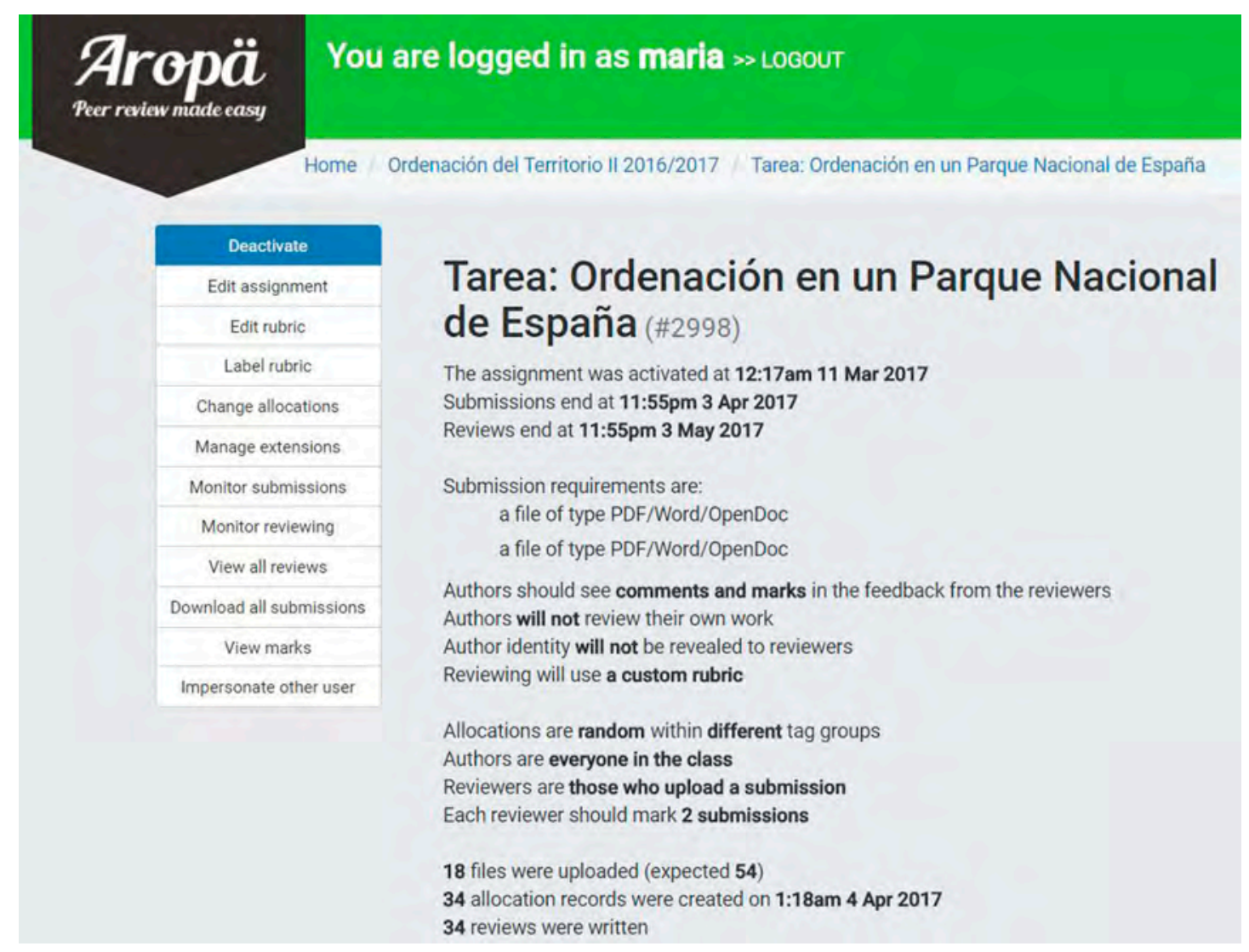

Figure 4. Aropä task for students.

Students peer reviewed the essays or dissertations, according a set of criteria statement (rubrics) established by the teacher (Table 2) in relation to the aspects of the work requested: guidelines on the format, adequacy of the chosen title, key information on the management of the park, enumeration of three relevant physical elements of the park, coherent explanatory discourse (clarity of ideas and argumentation, correct content, the theme is well centered), correct application of the concepts learned on the subject, inclusion of a personal contribution, suggesting new questions and reflections on the subject that opens bridges to later debates, correct spelling and grammatical expressions, 
and the use of an impersonal style or the third person. An item on satisfaction in reading other student's dissertations has been added.

Table 2. Rubrics already established for students and scores for each criterion.

\begin{tabular}{|c|c|c|}
\hline No. & Rubric & Score \\
\hline 1 & Meets the standards of the requested work & 1 \\
\hline 2 & The title chosen is attractive and according to the central topic & 1 \\
\hline 3 & Provide relevant information on the topic & 1 \\
\hline 4 & Deal with the main physical characteristics of the national park & 1 \\
\hline 5 & $\begin{array}{l}\text { Provide coherent discourse, clarity of ideas and argumentation; the theme or aspects } \\
\text { developed are correctly focused }\end{array}$ & 1 \\
\hline 6 & $\begin{array}{l}\text { Apply concept learned on the theme: (choose one) } \\
\text { - very good: covers everything, comprehensive, outstanding; } \\
\text { - good: covers most things, } \\
\text { - just adequate: some gaps; } \\
\text { - } \quad \text { poor: inadequate, shoes a lack of understanding) }\end{array}$ & $\begin{array}{l}2 \\
1 \\
1 \\
0\end{array}$ \\
\hline 7 & Contains a personal contribution & 1 \\
\hline 8 & Suggest new questions and reflections that open bridges to further discussion & 1 \\
\hline 9 & Correct content, spelling, and grammatical expressions & 1 \\
\hline 10 & Use an impersonal style or the third person & 1 \\
\hline 11 & Have you enjoyed reading the work? & 1 \\
\hline TOTAL & Maximum score & 12 \\
\hline
\end{tabular}

The student is invited to fill in a section of observations and the teacher gives some advice on how to correct a dissertation in a constructive way, collaborating in the improvement of the text and not in the disqualification of it. There are no absolute truths; everything has a temporal and spatial context. The value of new questions and reflections on the subject that have been raised will open bridges to subsequent debates and valuable personal contributions.

In this way, the student has approached three different Spanish national parks, one more in depth, elaborated by themself, and two other different parks through the correction made to their colleagues' dissertations. With it, students critically evaluate possible solutions according to the given criteria. They receive feedback on the form and content of the essay or dissertation already completed $[52,53]$. It is a system that favors discussion among students in an orderly way.

Therefore, the previous work of the teacher to elaborate the rubrics means that the tool allows attending to a great number of students with outcomes that reflect very reliable qualifications. The score differences between students themselves show more than 2.5 points in $18 \%$ of cases. The tutor/teacher worked on the peer review scores and compared with their own scores for the same student's dissertation. Teachers' scores do not differ from what the tool's creators have estimated after a deep study of the tool [54] (two points in 90\% of cases). Perhaps, more than two peer reviews will reduce the differences between student reviewer scores. Thus, it would be interesting to widen the blind peer review to a larger number of papers, e.g., five papers, which would undoubtedly enrich the feedback given to the students, the analysis and assessment of different landscapes, and would improve reliability of the evaluation.

\subsection{The Use of the Portfolio and Landscape Study}

The portfolio is a work tool that presents interesting aspects, such as the possibility of performing a cumulative, sequenced, and ordered work $[55,56]$, as well as the individual work and assimilation of content $[57,58]$. In this way, students will be able to participate in the process of reflection [59]. It also incorporates not merely descriptive learning, but is reasoned in such a way that it can be maintained over time and allows a reasoned application in future learning and research processes by the students 
involved [60]. In the context of personalized education, an educational action is employed, focused on each student being able to acquire knowledge and develop personal and civic virtues. The study of the landscape through the incorporation of the portfolio supposes the opportunity to incorporate, in an orderly and sequenced way, the accomplishment of tasks and spaces of study [61].

For the implementation of a conventional portfolio or an e-portfolio, if the students use the digital format, dedicated to landscape analysis, they must learn to select accurate and meaningful information, analyze it, and draw the appropriate conclusions. In the case of an urbanized landscape, it should represent the location of the general population in its population environment, i.e., neighborhoods, districts, and suburbs, analyzing the morphology of these settlements and obtaining conclusions about the incidence in the construction or transformation of the landscape. Significant indicators, such as population analysis, may also be used; for example, the degree of involvement on the landscape based on the level of education or professions in each neighborhood or district; The analysis of the regime of tenure of the dwellings (in property, rent, or assignment); The study of the number of persons occupying the dwelling and the age of the dwellings, level of personal autonomy (total, partial, or absolute), or the form of resolution in the case of any dependency (public, private, or concerted centers). All of these questions are based on the embodiment of the economic, cultural, or social spaces in which the population is located.

Another important section will consist of a map of facilities and services, including cultural and educational centers (libraries, universities, or centers of popular culture); health services (outpatient clinics, dispensaries, hospitals with geriatric services, among others); facilities for leisure, day centers (indicating ownership: public, private, or concerted), commercial services (pharmacies, banks, shops, and other companies), residences for seniors installed in the urban area (indicating ownership: public, private, or concerted, and the economic cost of the square), map of collective transport and its adaptation to the elderly, current state of the existence of architectural barriers, current state of urban furniture indicating the state of conservation of public toilets, banks in landscaped areas, or endowment indices for over 65 years in the different districts of the city, as well as the accessibility to the services in the different districts of the city.

Geography is the science of the scientific analysis of the landscape, so before arriving at the conclusions and proposals for improvement, a section dedicated to the population footprint in the urban landscape could not be missing in this proposal. Renovation of buildings in the neighborhoods, rehabilitation of buildings, intervention of public administrations in the preservation of residential and urban heritage, ending with the elaboration of a map of the studied neighborhood where the main urban actions for renovation and rehabilitation are reflected in the last decades, being able to perform for the qualitative analysis a survey on the level of citizen satisfaction by neighborhoods and proposals of improvement for a greater quality of life of elderly people. In this line of research, mental maps can also be very helpful [62].

Finally, regarding natural and cultural landscapes, the number of possibilities to incorporate the portfolio will be extraordinary, such as aspects of territorial planning to the knowledge of existing resources, or an educational work that will consist in raising awareness about the preservation and defense of these unique spaces [63].

The results obtained from the e-portfolio application to the classroom are summarized using the Likert scale (Table 3). The assessment by the users of the portfolio qualifies it as an effective learning tool, as it allows a good orientation in the monitoring of the contents, helps and orders the subject, and the autonomous learning obtains better results in the evaluation. All of them are facilitating elements to surpass the subject with success. 
Table 3. Valuation of portfolios by users.

\begin{tabular}{|c|c|c|c|c|c|}
\hline $\begin{array}{l}\text { Issues to De Valued about } \\
\text { the Use of Portfolios }\end{array}$ & $\begin{array}{l}\text { Complete } \\
\text { Disagree } 1\end{array}$ & $\begin{array}{c}\text { Partly } \\
\text { Disagree } 2\end{array}$ & Not Sure 3 & $\begin{array}{c}\text { Partly } \\
\text { Agree } 4\end{array}$ & $\begin{array}{l}\text { Fully } \\
\text { Agree } 5\end{array}$ \\
\hline 1. Facilitates the progress of learning & 0 & 3 & 12 & 11 & 4 \\
\hline 2. Allows an orderly rhythm in the subject & 0 & 2 & 9 & 13 & 5 \\
\hline 3. Constitute an effective learning tool & 1 & 0 & 4 & 19 & 6 \\
\hline 4. Promotes autonomous learning & 0 & 1 & 8 & 13 & 9 \\
\hline 5. Encourages interaction with teachers & 1 & 4 & 11 & 5 & 9 \\
\hline 6. Allows a positive evaluation & 0 & 1 & 7 & 14 & 8 \\
\hline 7. Directs the monitoring of the contents & 0 & 0 & 5 & 11 & 14 \\
\hline 8. Facilitates personalized attention & 2 & 6 & 10 & 5 & 7 \\
\hline
\end{tabular}

To facilitate the analysis and interpretation of data, a grouping of issues or items shown in Table 3 in dimensions or factors according to the theoretical structure of the instrument was performed, on which reliability data will be provided for internal consistency (Table 4).

In the first dimension, dedicated to the teaching-learning process, three items $(1,3$ and 4$)$ were grouped in total, proving that the reliability in the various groupings was satisfactory since Cronbach's alpha $(\alpha)$ allows estimating the reliability of an instrument measured through a set of items that are expected to measure the same construct or theoretical dimension. The measure of reliability by Cronbach's alpha assumes that the items (measured on the Likert scale) measure the same construct and are highly correlated. The closer the value of the alpha is to 1 , the greater the internal consistency of the analyzed items. The reliability of the scale must always be obtained with the data of each sample to guarantee the reliable measurement of the construct in the concrete research sample. As a general criterion [64], suggest the following recommendations to evaluate Cronbach's alpha coefficients: $>0.9$ is excellent; $>0.8$ is good; $>0.7$ is acceptable; $>0.6$ is questionable; and $>0.5$ is poor. In this section, the values oscillate between at least 0.741 (to facilitate the progress of the continuous learning), which reflects an acceptable coefficient, and 0.947 (autonomous learning), which reflects an excellent coefficient.

In the second dimension, items 2 and 7 were grouped, reliability was established between the ordered rhythm of the tasks and the ordered follow-up of the tasks, resulting in very high (0.94) and medium-high values (0.76).

Finally, the third dimension occupies three items $(5,6$ and 8) related to the interaction with teachers, the positive evaluation of the results, and personalized attention. In the three areas we obtain relatively high reliability data: personalized education reaches the highest value, above 0.9; while the contribution of the portfolio indicates a greater success in the overall evaluation of students, with indices between 0.90 and 0.80 ; finally, the interaction with teachers also represents elevated values always below 0.9 -in fact, we obtain indices between 0.87 and 0.85 , at a minimum.

Table 4. Grouping of items.

\begin{tabular}{llc}
\hline \multicolumn{1}{c}{ Items Grouped } & \multicolumn{2}{c}{ Reliability $(\boldsymbol{\alpha})$} \\
\hline Section I. Teaching and learning & Max & Min \\
\hline 1. Facilitates the progress of learning & 0.801 & 0.866 \\
3. Constitute an effective learning tool & 0.819 & 0.741 \\
4. Promotes autonomous learning & 0.866 & 0.756 \\
\hline Section II. Organization of the study & & \\
2. Allows an orderly rhythm in the subject /tasks & 0.947 & 0.764 \\
7. Directs the monitoring of the contents & 0.941 & 0.789 \\
\hline Section III. Evaluation and care & & \\
5. Encourages interaction with teachers & 0.872 & 0.853 \\
6. Allows a positive evaluation & 0.901 & 0.803 \\
8. Facilitates personalized attention & 0.933 & 0.901 \\
\hline
\end{tabular}




\section{Meta-Analysis of the Learning Experiences on Personalized Learning Indicators}

All learning examples are very different with respect to the tools despite the fact that they do not always have the same target audience, for example, using these tools in geography lessons with diverse students: some of them, on the first semester of the Master's Teacher Training course (the beginning of the fifth year at University). For its part, the Aropä tool was used on the last year of an Environmental Sciences degree (second semester, fourth year, undergraduate). However, a meta-analysis can be performed on the experiences provided by indicators dealing with personalized learning and related to the organization used (how), the software used (tools), the learning context or object (what) and, finally, the subjects or actors involved in the case of study (who): teachers and experts in learning and in the field, and a network of peer reviewers, are able to make an assessment of them (Table 5).

Table 5. Assessment of proposed activities based on the indicators considered by Zwartjes et al. [65] within the framework of personalized learning.

\begin{tabular}{|c|c|c|c|c|}
\hline Type & Personalized Learning Indicators & WebGIS & Aropä & E-Portfolio \\
\hline \multirow{5}{*}{ How } & Diagnostic entry test to start a real personalized learning trajectory & & & \\
\hline & Diagnostic tests during the personalized learning trajectory & $\mathrm{x}$ & $\mathrm{X}$ & $\mathrm{X}$ \\
\hline & Assessment at the end (via test and/or portfolio) & $\mathrm{x}$ & $\mathrm{x}$ & $\mathrm{x}$ \\
\hline & m-learning or u-learning instead of e-learning & & & \\
\hline & Take different learning styles into account & $\mathrm{x}$ & & $\mathrm{X}$ \\
\hline \multirow{5}{*}{ Tools } & Social network or other form of contact with co-learners included & $\mathrm{x}$ & $\mathrm{x}$ & \\
\hline & Interactivity & $x$ & $\mathrm{x}$ & $\mathrm{x}$ \\
\hline & Accessibility and usability of learning materials for everyone & $\mathrm{x}$ & $\mathrm{x}$ & $x$ \\
\hline & Monitoring via the system & & $\mathrm{X}$ & $\mathrm{x}$ \\
\hline & Motivation (entertainment) tools & $\mathrm{x}$ & & \\
\hline \multirow{6}{*}{ What } & Formal education $\rightarrow$ core-curriculum & $\mathrm{x}$ & $\mathrm{X}$ & $\mathrm{X}$ \\
\hline & Possibility (not obligatory) to include non-formal and informal learning & $\mathrm{x}$ & $\mathrm{x}$ & $x$ \\
\hline & Valuing all dimensions of the learner & & & $x$ \\
\hline & Valuing previous knowledge, competences, life and work skills, also informal & & & \\
\hline & Taking the cognitive background of the target group into consideration & $\mathrm{x}$ & $\mathrm{x}$ & $\mathrm{x}$ \\
\hline & Flexibility in the system (flexible content) & $\mathrm{x}$ & $\mathrm{X}$ & $\mathrm{X}$ \\
\hline \multirow{3}{*}{ Who } & Ownership of personalized learning & $\mathrm{x}$ & $\mathrm{x}$ & $\mathrm{x}$ \\
\hline & Instructor/tutor, experts and teachers to guide and support the learning & $\mathrm{x}$ & $\mathrm{x}$ & $x$ \\
\hline & Contact with peer group/cooperative learning & $\mathrm{X}$ & $\mathrm{X}$ & \\
\hline
\end{tabular}

Meta-analysis shows that personalized learning conducted by teachers is a useful way of learning, particularly with respect to distance learning, as more of the indicators have been put into practice in the learning experiences. The teacher intervention is essential in all cases to orient students and prepare the geoinformation instructional resources, which collaborative learning and the increasing interaction among students will enrich. The use of geoinformation tools, such as WebGIS, in different ways [66], combined with the use of other technologies, such as Aropä and e-portfolio, are very useful for a landscape approach. Different authors cited throughout the text have also used them for learning about the landscape, as they have many advantages, especially for those students for whom it is not possible to do fieldwork, as it occurs in distance learning.

\section{Conclusions}

Some challenges have been shown in distance teaching, such as achieving a personalized learning method, and the understanding and valuation of the landscape, the main object of geography. It has been considered necessary to clarify at the beginning what is understood by personalized teaching and how technology can help in applying it to university classes. Several examples have been set out when showing that it is possible to approach landscape study using geoinformation in the framework of personalized learning. 
In this way, the student and the teacher apply a methodology of distance learning in which the teacher will become a discrete mentor of student, learning through the teaching guides of the different subjects. The center of this learning is the student, who makes their own decisions regarding the range of materials and suggestions that the teacher provides.

Access to the virtual campus and other learning environments, such as Aropä, the monitoring of forums, videoconferences, and particularly the use of geoinformation, such as WebGIS, or the delivery of electronic portfolios, are complementary basic elements that contribute to the improvement of educational quality. Student participation and interaction with teachers improve teaching practice and the teaching-learning process, as evidenced by the positive evaluations of students using these tools. The results indicate that these tools have contributed to an improvement in the orderly follow-up of work, the contribution to meaningful learning, and the autonomy generated in the student body that has the peculiarity of working in an educational system based on distance learning. It is also a very useful tool in the process of evaluating the learnings and competencies acquired by the students.

Acknowledgments: The authors would especially like to thank all the core members of the Innovation and Improvement of Teaching Quality Project “Diseño de un modelo didáctico para la educación en paisaje utilizando SIGWeb" (A didactic model for the education in the landscape using WebGIS) (PIMCD 113/2017), which is funded by Universidad Complutense de Madrid and coordinated by José Manuel Crespo Castellanos. This research has been funded by the Spanish Ministry for Economy. National Plan for Scientific Research and Technological Development, project CSO2016-7488-C4-3-R, Indicadores multiescalares y herramientas cartográficas (GEOT-IUCA, Unizar) and for the dissemination of research results from the Vice-Rectorate for Research and Internationalization of the Universidad Nacional de Educación a Distancia (UNED).

Author Contributions: M.L.d.L.T. coordinated the team and conducted the research on personalized learning, WebGIS, and Aropä. R.D.M.G. coordinated the Digital School Atlas (ADE) and reviewed all articles for consistency and English language. F.J.M.Y. conducted research on personalized learning using e-portfolio.

Conflicts of Interest: The authors declare no conflict of interest.

\section{Appendix}

List of PIMCD projects on learning landscape:

1. “Enseñar Geografía a través del análisis de imágenes con la ayuda del Campus Virtual y la Pizarra Digital Interactiva (PDI)" (Teaching Geography and image analysis using Virtual Campus and the Interactive Whiteboard, IWB), PIMCD 6/2010. (Coordinator Dr. Da María Luisa de Lázaro y Torres). Available online: <http:/ / eprints.ucm.es/16849/> (accessed on 11 September 2017).

2. "Aprender Geografía con la web 2.0" (Learning Geography using 2.0 Web). PIMCD 133/ 2011. (Coordinator Dr. Da María Luisa de Lázaro y Torres). Available online: <http:/ / eprints.ucm.es/ 21217/> (accessed on 11 September 2017).

3. “Aprender Geografía de España con la web 2.0" (Learning Spanish geography on the Web 2.0). PIMCD 165/ 2013. (Coordinator Dr. D. Miguel Ángel Alcolea Moratilla). Available online: <http:/ / eprints.ucm.es/27995/> (accessed on 11 September 2017).

4. "Aprender Geografía con la web 2.0 a través de la evolución de los paisajes agrarios de España"( Learning Geography with the $2.0 \mathrm{Web}$ and Spanish agrarian landscapes changes). PIMCD 98/ 2014. (Coordinator Dr. D Daría Luisa de Lázaro y Torres). Available online: <http:/ / eprints.ucm.es/28547/> (accessed on 11 September 2017).

5. "La potencialidad de la nube para el trabajo de campo en Geografía: El Parque Nacional de la Sierra de Guadarrama" (The challenge of the Cloud for fieldwork in geography: the Sierra de Guadarrama National Park). PIMCD 224/2015. (Coordinator Dr. D. José Manuel Crespo Castellanos). Available online: <http:/ / eprints.ucm.es/35335/> (accessed on 11 September 2017).

6. “Aplicación de las tecnologías de la información geográfica en el diseño de itinerarios para la educación en paisaje en el ámbito de los Parques Nacionales Españoles"(Application of GeoICT in the design of itineraries for landscape education in the field of Spanish National Parks). PIMCD 52/2016. (Coordinator Dr. D. José Manuel Crespo Castellanos.) 


\section{References}

1. Thompson, D.; Lindsay, F.E.; Davis, P.E.; Wong, D.W. Towards a framework for learning with GIS: The case of urban world, a hypermap learning environment based on GIS. Trans. GIS 1997, 2, 151-167. [CrossRef]

2. Silavi, T.; Hakimpour, F.; Claramunt, C.; Nourian, F. The Legibility and Permeability of Cities: Examining the Role of Spatial Data and Metrics. ISPRS Int. J. Geo-Inf. 2017, 6, 101. [CrossRef]

3. De Miguel, R.; De Lázaro, M.L. Educating geographers in Spain. Geography teaching renewal by implementing the European Higher Education Area. J. Geogr. High. Educ. 2016, 40, 267-283. [CrossRef]

4. Favier, T.T.; Van Der Schee, J.A. The effects of geography lessons with geospatial technologies on the development of high school students' relational thinking. Comput. Educ. 2014, 76, 225-236. [CrossRef]

5. Baker, T.R.; Battersby, S.; Bednarz, S.W.; Bodzin, A.M.; Kolvoord, B.; Moore, S.; Sinton, D.; Uttal, D.A. Research Agenda for Geospatial Technologies and Learning. J. Geogr. 2015, 114, 11-130. [CrossRef]

6. Carbonell, C.; Bermejo, L.A. Augmented reality as a digital teaching environment to develop spatial thinking. Cartogr. Geogr. Inf. Sci. 2017, 44, 259-270. [CrossRef]

7. Carbonell, C.; Avarvarei, B.V.; Chelariu, E.L.; Draghia, L.; Avarvarei, S.C. Map-Reading Skill Development with 3D Technologies. J. Geogr. 2017, 116, 197-205. [CrossRef]

8. Elosúa, M.R. El aprendizaje significativo desde un enfoque social. Revista de Psicología Universitas Tarraconensis 1992, 2, 7-16.

9. Europe, C.O. Convención Europea del Paisaje; Council of Europe: Florence, Italy, 2000.

10. Crespo Castellanos, J.M. La Educación en Paisaje en el Grado de Maestro de Educación Primaria: Una Propuesta de Modelo Didáctico (Landscape Education in Primary Teacher's Degree: A Didactic Model proposal). Ph.D. Thesis, Complutense University of Madrid, Madrid, Spain, 23 June 2017.

11. Observatorio de Educación Patrimonial en España (OEPE) (Web of the Observatory of Heritage Education in Spain). Ministerio de Economía-FECYT. Available online: http: / www.oepe.es / (accessed on 19 August 2017).

12. Fontal, O.; Ibáñez, A. Estrategias e instrumentos para la educación patrimonial en España. Educatio Siglo XXI 2015, 33, 15-32. [CrossRef]

13. Pereira, N. Educación Personalizada: Un Proyecto Pedagógico en Pierre Faure; Narcea: Madrid, Spain, 1976.

14. Kerski, J.J. Sleepwalking into the Future-The Case for Spatial Analysis Throughout Education. In Learning with GI 2011; Jekel, T., Koller, A., Donert, K., Vogler, R., Eds.; Herbert Wichmann Verlag: Berlin/Offenbach, Germany, 2011.

15. Favier, T.; Van Der Schee, J. Exploring the characteristics of an optimal design for inquiry-based geography education with Geographic Information Systems. Comput. Educ. 2012, 58, 666-677. [CrossRef]

16. Buzo, I. Incorporación de un WebSIG a la enseñanza de la Geografía en $3^{\circ}$ de ESO. In Actas XVI Congreso Nacional de Tecnologías de la Información Geográfica; Universidad de Alicante: Alicante, Spain, 2014; pp. 711-720.

17. De Lázaro, M.L.; De Miguel, R.; González, M.J. Flipped teaching: A useful method for cloud-based GIScience learning. In Educational Design and Cloud Computing in Modern Classroom Settings; Doukas, K., Kostopoulos, K., Eds.; IGI Global: Hershey, PA, USA, 2017, accepted.

18. Sams, A.; Bergmann, J. Flip Your Classroom: Reach Every Student in Every Class Every Day; International Society for Technology in Education/ISTE: Arlington, VA, USA, 2012.

19. Mitra, S. SOLE Toolkit: How to Bring Self-Organized Learning Environments to Your Community. Available online: http:/ / media.ted.com/storage/prize/SOLEToolkit.pdf (accessed on 11 June 2013).

20. European Union. Recommendation of the European Parliament and of the Council of 18 December 2006 on Key Competences for Lifelong Learning (2006/962/EC). J. Eur. Union 2006, L394/10-L394/18.

21. Adams Becker, S.; Cummins, M.; Davis, A.; Freeman, A.; Hall Giesinger, C.; Ananthanarayanan, V. NMC Horizon Report: 2017 Higher Education Edition; The New Media Consortium: Austin, TX, USA, 2017.

22. Mishra, P.; Koehler, M.J. Technological pedagogical content knowledge: A framework for integrating technology in teacher knowledge. Teach. Coll. Rec. 2006, 108, 1017-1054. [CrossRef]

23. Mishra, P.; Koehler, M.J. What is technological pedagogical content knowledge (TPACK)? Cont. Issues Technol. Teach. Educ. 2009, 9, 60-70.

24. Su, X.; Huang, X.; Zhou, C.; Chang, M. A Technological Pedagogical Content Knowledge (TPACK) Scale for Geography Teachers in Senior High School. Egitim ve Bilim 2017, 42, 325-341. [CrossRef]

25. Doering, A.; Koseoglu, S.; Scharber, C.; Henrickson, J.; Lanegran, D. Technology integration in K-12 geography education using TPACK as a conceptual model. J. Geogr. 2014, 113, 223-237. [CrossRef] 
26. Mohd, C.K.; Nuraini, C.K.; Shahbodin, F.; Pee, N.C.; Hanapi, C. Personalized learning environment (PLE) experience in the 21st century: Review of literature. In Third World Congress on Information and Communication Technologies (WICT 2014); MITC: Melaka, Malaysia, 2014. Available online: http:/ / eprints.utem.edu.my/13777/ (accessed on 19 August 2017).

27. Cejas León, R.; Navío Gámez, A.; Barroso Osuna, J. Las competencias del profesorado universitario desde el modelo TPACK (conocimiento tecnológico y pedagógico del contenido). Pixel-Bit Revista de Medios y Educación 2016, 49, 105-199. [CrossRef]

28. Álvarez, J.; De Lázaro, M.L. Spatial Data Infrastructure and Learning Geography. Eur. J. Geogr. 2017, 8, $19-29$.

29. Krathwohl, D.R. A revision of Bloom's taxonomy: An overview. Theory Pract. 2002, 41, 212-218. [CrossRef]

30. Purchase, H.C.; Hamer, J. Peer Review in Practice: Eight years of experiences with Aropä. School of Computing Science, University of Glasgow. Assess. Eval. High. Educ. 2017, 1-15. [CrossRef]

31. Fidalgo, Á.; Sein-Echaluce, M.L.; Lerís, D.; Castañeda, O. Teaching Innova Project: The Incorporation of Adaptable Outcomes in Order to Grade Training Adaptability. J. UCS 2013, 19, 1500-1521.

32. Dziuban, C.; Moskal, P.; Johnson, C.; Evans, D. Adaptive Learning: A Tale of Two Contexts. Curr. Issues Emerg. $2017,4,3$.

33. Buchem, I.; Attwell, G.; Torres, R. Understanding personal learning environments: Literature review and synthesis through the activity theory lens. In Proceedings of the PLE Conference 2011, Southampton, UK, 10-12 July 2011; pp. 1-33. Available online: http:/ /journal.webscience.org/658/ (accessed on 19 August 2017).

34. Lázaro, M.L.; De Miguel, R.; Buzo, I. El proyecto School on the Cloud: Lecciones aprendidas (School on the Cloud project: Lessons learned). Espacio Tiempo y Forma Serie VI Geografía 2017, 345-362. [CrossRef]

35. Martinez, M. Key design considerations for personalized learning on the web. Educ. Technol. Soc. 2001, 4, $26-40$.

36. Lázaro, M.L.; Buzo, I. Aprender empleando SIGWebs. In IX Jornadas de Redes de Investigación en Innovación Docente de la UNED. La Profesionalización del Docente a Través de la Innovación Educativa; UNED: Madrid, Spain, 2017, in press.

37. Lwin, K.K.; Murayama, Y. Web-based GIS system for real-time field data collection using personal mobile phone. J. Geogr. Inf. Syst. 2011, 3, 382-389. [CrossRef]

38. Milson, A.J. GIS in the Cloud: Using WebGIS for Teaching Secondary Geography. Didáct. Geogr. 2011, 12, 151-153.

39. GeoSkills Plus Project. Landmeter: Revue Trimestrielle de l'Union Belge des Géomètres-Experts et l'Association Nationale des Géomètres-Experts. 2015. Available online: http://www.obge-bole.be/ GetDocument.ashx?nr=1033 (accessed on 19 August 2017).

40. Lázaro y Torres, M.L.; González González, M.J.; Mínguez García, M.C.; Mecha López, R.; Palacios Estremera, M.T.; Ruiz Palomeque, M.E. Enseñar Geografía a Través del Análisis de Imágenes con la Ayuda del Campus Virtual y la Pizarra Digital Interactiva (PIMCD 6/2010); Cersa: Madrid, Spain, 2012. Available online: http:/ / eprints.ucm.es/16849/ (accessed on 19 August 2017).

41. Alcolea Moratilla, M.A.; Buzo Sánchez, I.; Crespo Castellanos, J.M.; Cruz Naïmi, L.A.; De Lázaro y Torres, M.L.; De Miguel González, R.; Delgado Peña, J.J.; Gómez Ruiz, M.L.; González Castañé, M.; González González, M.J.; et al. Aprender Geografía de España con la Web 2.0; Vicerrectorado de Evaluación de la Calidad de la Universidad Complutense de Madrid: Madrid, Spain, 2014. Available online: http:/ / eprints.ucm.es/27995 (accessed on 19 August 2017).

42. Lázaro y Torres, M.L.; Alcolea Moratilla, M.A.; Buzo Sánchez, I.; Crespo Castellanos, J.M.; Cruz Naïmi, L.A.; De Miguel González, R.; Delgado Peña, J.J.; Gómez Ruiz, M.L.; González González, M.J.; Guallart Moreno, C.; et al. Aprender Geografía con la Web 2.0 a Través de la Evolución de los Paisajes Agrarios de España; Universidad Complutense de Madrid: Madrid, Spain, 2015. Available online: http:/ / eprints.ucm.es/28547/ (accessed on 19 August 2017).

43. Lázaro, M.L.; Izquierdo, S.; González, M.J. Geodatos y paisaje: De la nube al aula universitaria (Geodata and landscape: From the Cloud to Lectures). Bol. Asoc. Geógr. Esp. 2016, 70, 371-391. [CrossRef]

44. Buzo, I.; De Miguel, R.; De Lázaro, M.L. Learning on the cloud about changes to rural landscape and ArcGIS Online. In Proceedings of the 6th International Conference on Education and New Learning Technologies, Barcelona, Spain, 7-9 July 2014; pp. 248-255.

45. Álvarez, J.; De Lázaro, M.L.; González, M.J. A Cloud-based GIScience Learning Approach to Spanish National Parks. Eur. J. Geogr. 2017, under review.

46. De Miguel, R.; De Lázaro, M.L.; Velilla, J.; Buzo, I.; Guallart, C. Atlas Digital Escolar: Internet, Geografía y Educación. In Ar@cne. Revista Electrónica de Recursos de Internet Sobre Geografía y Ciencias Sociales; Universidad de Barcelona: Barcelona, Spain, 2016. Available online: http:/ / www.ub.edu/geocrit/aracne/aracne-212.pdf (accessed on 19 August 2017). 
47. ESRI. What Is ArcGIS Online? Available online: http://doc.arcgis.com/en/arcgis-online/reference/whatis-agol.htm (accessed on 28 October 2017).

48. De Miguel, R.; Buzo, I.; De Lázaro, M.L. New challenges for geographical education and researching: The Digital School Atlas. In Crisis, Globalization and Social and Regional Imbalances in Spain; Spanish Contribution to $33^{\text {rd }}$ IGU Congress Beijing 2016; pp. 187-197. Available online: http:/ / www.age-geografia.es/site/wpcontent/uploads/2016/07/crisis_globlalization_UGI_eng_2016_WEB.pdf (accessed on 19 August 2017).

49. Kim, M.; Bednarz, R. Development of critical spatial thinking through GIS learning. J. Geogr. High. Educ. 2013, 37, 350-366. [CrossRef]

50. Solem, M.; Huynh, N.T.; Boehm, R. Learning Progressions for Maps, Geospatial Technology, and Spatial Thinking: A Research Handbook; Cambridge Scholars Publishing and Association of American Geographers: Washington, DC, USA, 2015.

51. Lázaro, M.L.; Morales, F.J.; Zárate, M.A. La valoración del paisaje en el marco del aprendizaje personalizado y la educación a distancia (Landscape assessment in the framework of personalized learning and distance education). In Proceedings of the XXV Congreso de la AGE (Spanish Geographical Association) “Naturaleza, Territorio y Ciudad en un Mundo Global", Madrid, Spain, 25-27 October 2017; pp. 2690-2699.

52. Hamer, J.; Luxton-Reilly, A.; Purchase, H.C.; Sheard, J. Tools for contributing student learning. ACM Inroads 2011, 2, 78-91. [CrossRef]

53. Hamer, J.; Purchase, H.; Luxton-Reilly, A.; Denny, P. A Comparison of Peer and Tutor Feedback. Assess. Eval. High. Educ. 2015, 40, 151-164. [CrossRef]

54. Hamer, J.; Purchase, H.C.; Denny, P.; Luxton-Reilly, A. Quality of peer assessment in CS1. In Proceedings of the Fifth International Workshop on Computing Education Research Workshop, Berkeley, CA, USA, 10-11 August 2009; pp. 27-36.

55. Pérez, R. El Portfolio. Aprendizajes, Competencias y Evaluación; UNED: Madrid, Spain, 2012.

56. Calero, A.; Calero, E. El portfolio como estrategia de evaluación compartida de la comprensión lectora. Didáctica 2008, 15-36. [CrossRef]

57. Barberà, E. El Estilo E-Portafolio; Editorial UOC: Barcelona, Spain, 2008.

58. Barberà, E.; Gewerc Barujel, A.; Rodríguez Illera, J. Portafolios electrónicos y educación superior en España: Situación y tendencias. Revista Educ. Distancia 2016. [CrossRef]

59. Morales, F.J. La incorporación de los portafolios electrónicos en el proceso de enseñanza-aprendizaje y evaluación de la Geografía en el alumnado de educación a distancia (The incorporation of electronic portfolios learning in geography and evaluation process in distance). Geografía 2016, 231-240. [CrossRef]

60. Agra, M.J.; Gewerc, A.; Montero, L. El portafolio como herramienta de análisis en experiencias de formación on line y presenciales (The portfolio as an analysis instrument for on-line and educational experiences). Enseñanza Teach. 2003, 21, 101-114.

61. Morales, F.J. El portfolio electrónico como recurso didáctico en Geografía. Análisis y valoración por alumnado del máster universitario de investigación en la UNED. In Actas del XVIII Congreso Internacional de Didáctica de las Ciencias Sociales; Universidad de Córdoba: Andalusia, Spain, 2017; pp. 697-707.

62. Zárate, M.A. Imágenes mentales del Centro de Madrid, el barrio de Lavapiés. Boletín Real Soc. Geogr. 2001, CXXXVII, 403-423.

63. Zárate, M.A. Paisajes culturales urbanos, oportunidad para la conservación del patrimonio y el turismo sostenible. Estudios Geográficos 2017, 77, 693-728. [CrossRef]

64. George, D.; Mallery, P. SPSS for Windows Step by Step: A Simple Guide and Reference, 11.0 Atualização (4 ${ }^{a}$ edição); Allyn \& Bacon: Boston, MA, USA, 2003.

65. Zwartjes, L. Guidance on Personalised Learning and the Cloud. 2016. Available online: http://www. schoolonthecloud.net/copy-of-case-studies-of-personalise (accessed on 19 August 2017).

66. Muñiz Solari, O.; Demirci, A.; Van der Schee, J. Geospatial Technologies and Geography Education in a Changing World: Geospatial Practices and Lessons Learned; Springer: New York, NY, USA, 2015; 221p.

(C) 2017 by the authors. Licensee MDPI, Basel, Switzerland. This article is an open access article distributed under the terms and conditions of the Creative Commons Attribution (CC BY) license (http://creativecommons.org/licenses/by/4.0/). 